LA WRENCE LIWEAMCAE NATIONAL LABDAATOAY

LLNL 10(a)(1)(A) Annual
Report (TE-053672-2)--2006

J. Woollett

January 31, 2007 
This work was performed under the auspices of the U.S. Department of Energy by University of California, Lawrence Livermore National Laboratory under Contract W7405-Eng-48.

This document was prepared as an account of work sponsored by an agency of the United States Government. Neither the United States Government nor the University of California nor any of their employees, makes any warranty, express or implied, or assumes any legal liability or responsibility for the accuracy, completeness, or usefulness of any information, apparatus, product, or process disclosed, or represents that its use would not infringe privately owned rights. Reference herein to any specific commercial product, process, or service by trade name, trademark, manufacturer, or otherwise, does not necessarily constitute or imply its endorsement, recommendation, or favoring by the United States Government or the University of California. The views and opinions of authors expressed herein do not necessarily state or reflect those of the United States Government or the University of California, and shall not be used for advertising or product endorsement purposes. 


\section{LLNL 10(a)(1)(A) Annual Report (TE-053672-2)--2006}

\section{Introduction}

This report summarizes research related to Lawrence Livermore National Laboratory's (LLNL) Experimental Test Site, Site 300 (S300), located within Alameda and San Joaquin Counties (Figure 1) and conducted under the 10(a)(1)(A) (Recovery) permit TE-053672-

2. The U.S. Department of Energy / National Nuclear Security Administration (NNSA) holds this property in ownership. The 2006 recovery research at S300 involved fieldwork associated with two species: the California whipsnake (Masticophis lateralis) (MALA) and the California red-legged frog (Rana aurora draytonii) (CRLF).

\section{Background}

A research project (Biological Opinion \#1-1-02-F-0064) investigating the direct effects (fatality/harm) and indirect impacts (habitat alteration) of prescribed burning of coastal sage scrub on MALA was permitted by the U.S. Fish and Wildlife Service (Service), Sacramento Office, in the Spring of 2002. Several different public resource management agencies were approved by the Service to implement recovery-oriented (fuels treatment) studies associated with this research plan. LLNL's proposed seven-year study was initiated in 2002 and is anticipated to conclude in 2008. Results reflected in this report apply to information gathered during the first five years of the project; because of the low MALA sample size collected onsite and the unforeseen wildland fire that burned both of the study sites in 2005, longterm conservation-related measures for MALA are not yet evident from study analyses.

The CRLF research (Biological Opinion\# 1-1-02-F-0062) involved translocating individuals from two wetland locations that had received artificial (potable) water discharges for the last 15-20 years. CRLF's that occupied the wetland sites were moved to an enhanced wetland area further downstream (engineered pools in a pre-existing perennial drainage) in an area called "Mid-Elk Ravine." The aboveground, potable water flows were terminated once all CRLF translocations had been completed (Summer of 2006).

\section{Methodology}

For a complete discussion of the methodology associated with the MALA research project see "Research Proposal: Effects of Prescribed Burns on the California whipsnake" (Swaim 2002) which was attached to the annual 10(a)(1)(A) (Recovery) permit report of 2005. Trapping and marking individual MALA in both the North and South scrubland sites continued in 2006 at S300 (Figure 2) and represented the first trapping effort since the Summer 2005 wildland burn. The trapping period duration consisted of a total of 42.25 days (Table 1) from April 27 to July 14, 2006. Trapping dates were divided into three separate periods relating to fire effects: Period B (pre-burn), Period PB (prescribed burn; affected South scrubland site only), and Period WB (wildland burn; affected both North and South scrubland sites).

CRLF tagging and translocation in March and April, 2006, were performed in a manner consistent with the Mitigation and Monitoring Plan (see attachment to 2005 annual 10(a)(1)(A) (Recovery) permit report). LLNL was trained by Trish Tatarian (Greg and Trish Tatarian, Wildlife Research Associates, 1119 Burbank Ave., Santa Rosa, CA 95407) 
to use Passive Integrated Transponder tags (PIT) and belt-transmitters. Monitoring of CRLF presence and breeding success at the Mid-Elk Ravine enhancement pools occurred primarily between February and March and in October of 2006.

\section{$\underline{\text { Results }}$}

Spring trapping resulted in the capture of 3 new MALA individuals ( 2 males, 1 female) and the recapture of 2 previously tagged MALA individuals ( 1 male, 1 female). Individual numbers and total numbers of snakes captured per trap day for the 20022006 study period are reflected in Figures 3, showing that slightly higher MALA captures have occurred in the North scrubland overtime. Snake capture rates diminished since the prescribed burn. Period WB consisted of substantially less days than the other two Periods but suggests that MALA presence continues to be low on the study sites after the burn perturbation(s). The apparent rise in total capture number in the North scrubland in period WB is misleading because the cumulative snake sample size is very low.

Figure 4 displays an aerial photograph of the translocation project area with the two manmade wetland (B865 and B801) sites that served as CRLF collection points.

Monitoring of the Mid-Elk Ravine enhancement pools resulted in observations of colonization, breeding, egg laying, larvae development, and young of the year recruitment of CRLF at the new pools in 2006 (Table 2). Besides the translocation of adults to this site, other CRLF adults colonized the upper and lower pool areas from surrounding areas. Egg masses were observed in both pools by the end of March; larvae were abundant in both pools and some individuals were even present beyond October of 2006. In September of 2006, recently metamorphosed, terrestrial CRLF numbered in the hundreds around the periphery of both the upper and lower pools.

Eight frogs were translocated on March 23, 2006 from the B865 wetland (four adult males, three adult females, one young of the previous year), and eight more frogs were translocated on April 6, 2006 from the B865 wetland (five adult males, two adult females, one young of the previous year). All frogs received PIT tags and a belt radio transmitter except for the young of the year. All transmittered frogs were tracked for the duration of the battery life (approximately 3.5 months). Based on the transmitter signal and observations of individual frogs during that time period, 13 of the 14 transmittered frogs stayed in the Mid-Elk Ravine enhancement pool after translocation. One male returned to the original wetland at B865; his radio signal was not detected the day after completing this movement.

Ten frogs were translocated on August 25, 2006 from the B801 wetland (seven adult males; two adult females; one young of the previous year). Due to the extreme temperatures of the season and potential stress associated with the translocation process, no frogs were tagged or transmittered during this move. Based on monitoring the B801 site, no individuals are believed to have returned to the B801 wetland during the subsequent weeks. 


\section{Discussion/Conclusion}

Low sample size in 2006 ( $n=3$ new captures; $n=2$ recaptures) makes it difficult to correlate any trends or findings of significance for the spring trapping of MALA. Overall, snake captures dropped between Period B and PB, possibly indicating that the Prescribed fire impacted both the South scrubland and the adjacent unburned North scrubland that the MALA use of the sites. The North scrubland appears to have a slightly larger number of active MALA and may respond with a post-fire population increase more quickly than MALA that utilize the South scrubland area.

MALA \#26, originally captured in the South scrubland, was trapped in the North scrubland in 2006. This is the second snake (both males) to have been successfully captured beyond a Period or after fire effects that demonstrated a use of both study sites. Although there are only two individuals showing this movement capability, these results suggest that male MALA at S300 may not be confined to single scrub patches of approximately 15 acres but can utilize a larger area for foraging and breeding, especially of burned sites.

The spring translocation of 16 CRLF and their fidelity to the Elk Ravine sites through the summer suggests that the relocation attempt was successful. No findings of the CRLF that returned to the B801 wetland imply that these individuals also stayed in the Mid-Elk Ravine area.

Colonization of the Mid-Elk Ravine pools by other CRLF in the area implies that the site offered suitable habitat for the species, and offered a number of open niche positions. Spring breeding and summer metamorphosis by CRLF was documented at the sites, and young of the year were observed at the pools at night in October (CRLF juveniles are normally more active during diurnal periods) which shows that population recruitment and use of the area continue to occur. Further monitoring and observations of this frog population will be ongoing in 2007. 


\section{REFERENCES}

Swaim Biological Consulting. 2002. Research Proposal: Effects of Prescribed Burns on the California whipsnake (Masticophis lateralis euryxanthus). Prepared for H. Bell, Research Branch, Endangered Species Division, USFWS, Sacramento Office. 
Table 1. Organization of MALA trapping periods based on Period B (Pre-burn), Period PB (Prescribed burn in South scrubland only), and Period WB (Wildland burn in both North and South scrubland sites).

Trapping Periods 2002-2006

\begin{tabular}{|c|c|c|c|}
\hline \multicolumn{4}{|l|}{ Period B } \\
\hline Spring 2002 & $\begin{array}{l}\text { Opened } \\
4 / 15\end{array}$ & $\begin{array}{l}\text { Closed } \\
7 / 1\end{array}$ & 63 days total \\
\hline Fall 2002 & $\begin{array}{l}\text { Opened } \\
8 / 14\end{array}$ & $\begin{array}{l}\text { Closed } \\
10 / 15\end{array}$ & 33.75 days total \\
\hline Spring 2003 & $\begin{array}{l}\text { Opened } \\
4 / 18\end{array}$ & $\begin{array}{l}\text { Closed } \\
6 / 23 \\
\end{array}$ & 37 days total \\
\hline \multicolumn{4}{|l|}{ Period PB } \\
\hline Fall 2003 & $\begin{array}{l}\text { Opened } \\
8 / 20\end{array}$ & $\begin{array}{l}\text { Closed } \\
11 / 7\end{array}$ & 29.75 days total \\
\hline Spring 2004 & $\begin{array}{l}\text { Opened } \\
4 / 19\end{array}$ & $\begin{array}{l}\text { Closed } \\
6 / 25\end{array}$ & 48.25 days total \\
\hline Fall 2004 & $\begin{array}{l}\text { Opened } \\
8 / 22\end{array}$ & $\begin{array}{l}\text { Closed } \\
10 / 08\end{array}$ & 34.75 days total \\
\hline Spring 2005 & $\begin{array}{l}\text { Opened } \\
5 / 02\end{array}$ & $\begin{array}{l}\text { Closed } \\
6 / 30\end{array}$ & 36.25 days total \\
\hline
\end{tabular}

\section{Period WB}

$\begin{array}{llll} & \text { Opened } & \text { Closed } & \\ \text { Spring 2006 } & 4 / 27 & 7 / 14 & 42.25 \text { days total }\end{array}$


Table 2: Results of monitoring for California red-legged frog egg masses and young of the year at the Mid-Elk Ravine Mitigation Pools.

\begin{tabular}{|c|c|c|c|c|c|}
\hline $\begin{array}{l}\text { Mid-Elk } \\
\text { Ravine }\end{array}$ & Date & $\begin{array}{c}\text { Number of egg } \\
\text { masses } \\
\text { observed }\end{array}$ & $\begin{array}{c}\text { Egg success } \\
\text { (emergence) } \\
{[\text { Yes/No] }}\end{array}$ & $\begin{array}{l}\text { Egg mass } \\
\text { attachment } \\
\text { structure }\end{array}$ & $\begin{array}{l}\text { Number of } \\
\text { Ad / Young of the } \\
\text { year frogs } \\
\text { observed }\end{array}$ \\
\hline Upper pool & $\begin{array}{c}2 / 15- \\
3 / 30 / 06\end{array}$ & 2 & Yes & $\begin{array}{l}\text { Submerged } \\
\text { Brassica \& } \\
\text { Salsola sp. }\end{array}$ & Up to $5 / 0$ \\
\hline \multirow{3}{*}{ Lower pool } & $\begin{array}{c}10 / 19 \& \\
10 / 26 / 06\end{array}$ & $\mathrm{n} / \mathrm{a}$ & Yes & $\mathrm{n} / \mathrm{a}$ & Average $=11 / 16$ \\
\hline & $\begin{array}{c}2 / 15- \\
3 / 30 / 06\end{array}$ & 3 & Yes & $\begin{array}{l}\text { Submerged } \\
\text { Brassica \& } \\
\text { Salsola sp. }\end{array}$ & Up to $6 / 0$ \\
\hline & $\begin{array}{c}10 / 19 \& \\
10 / 26 / 06\end{array}$ & $\mathrm{n} / \mathrm{a}$ & Yes & $\mathrm{n} / \mathrm{a}$ & Average $=9 / 12$ \\
\hline
\end{tabular}




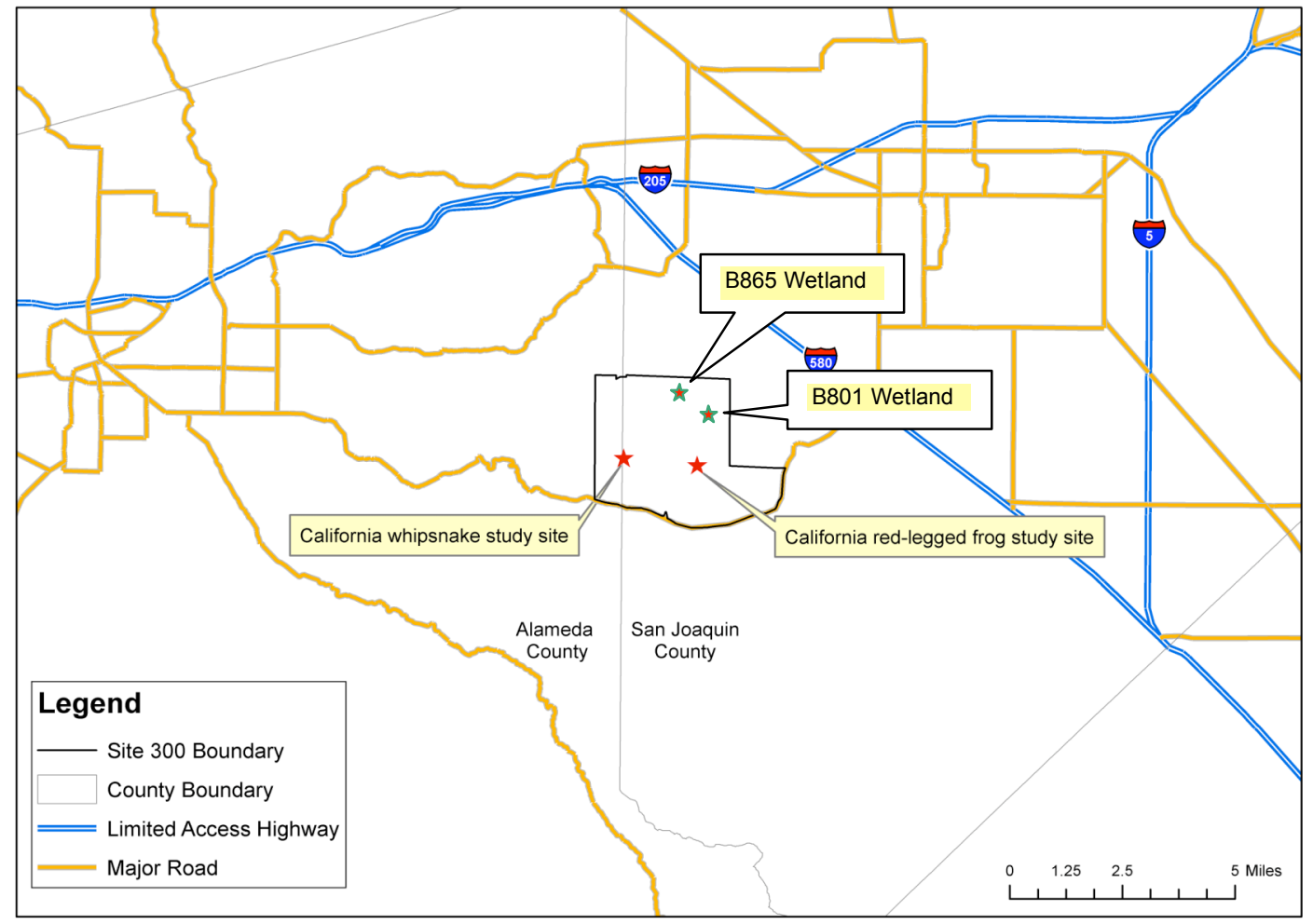

Figure 1. Regional location of California whipsnake and California red-legged frog study sites with respect to the Lawrence Livermore National Laboratory, Site 300 property. 

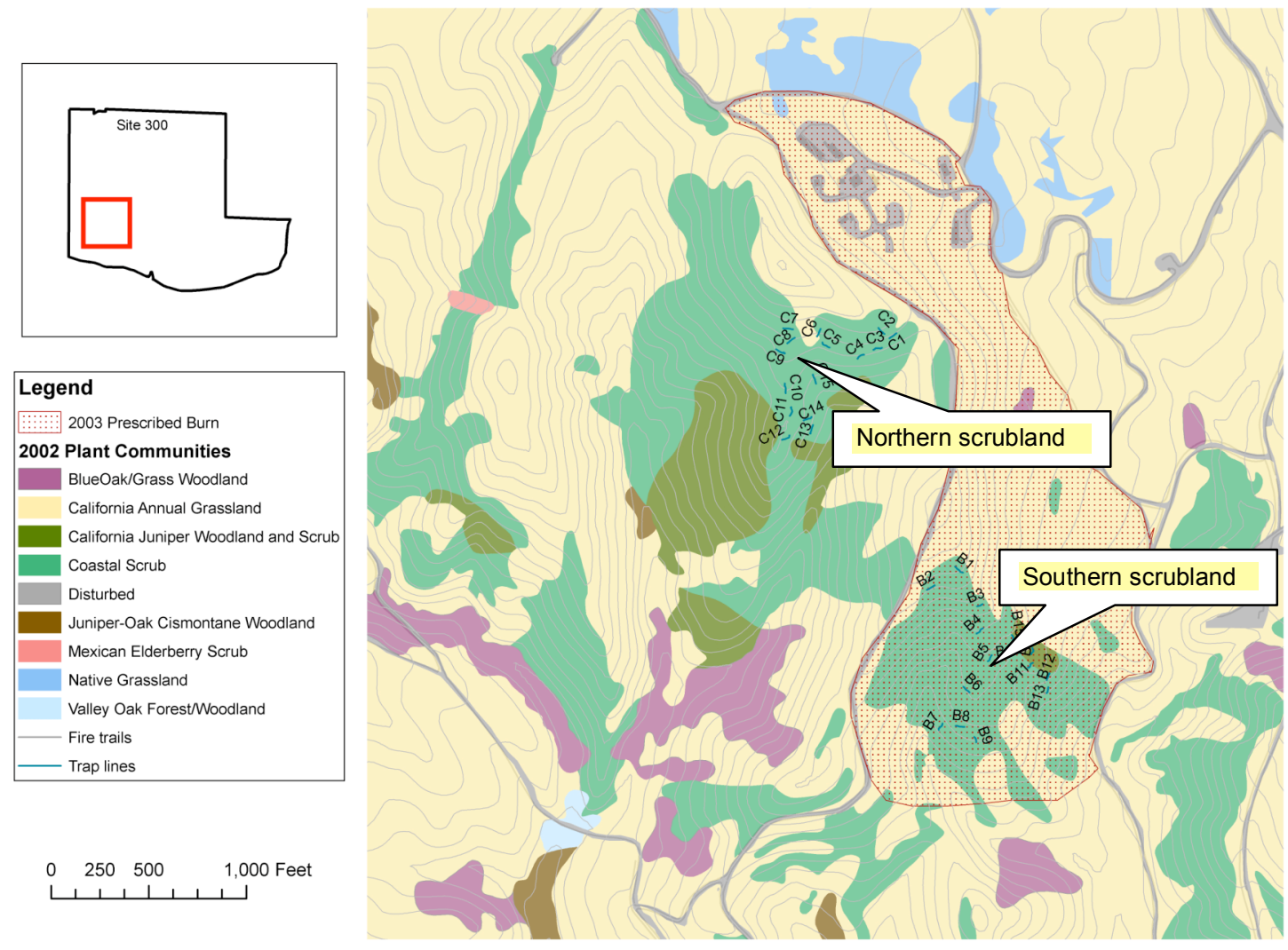

Figure 2. Location of California whipsnake trap lines and 2003 Spring prescribed burn. 

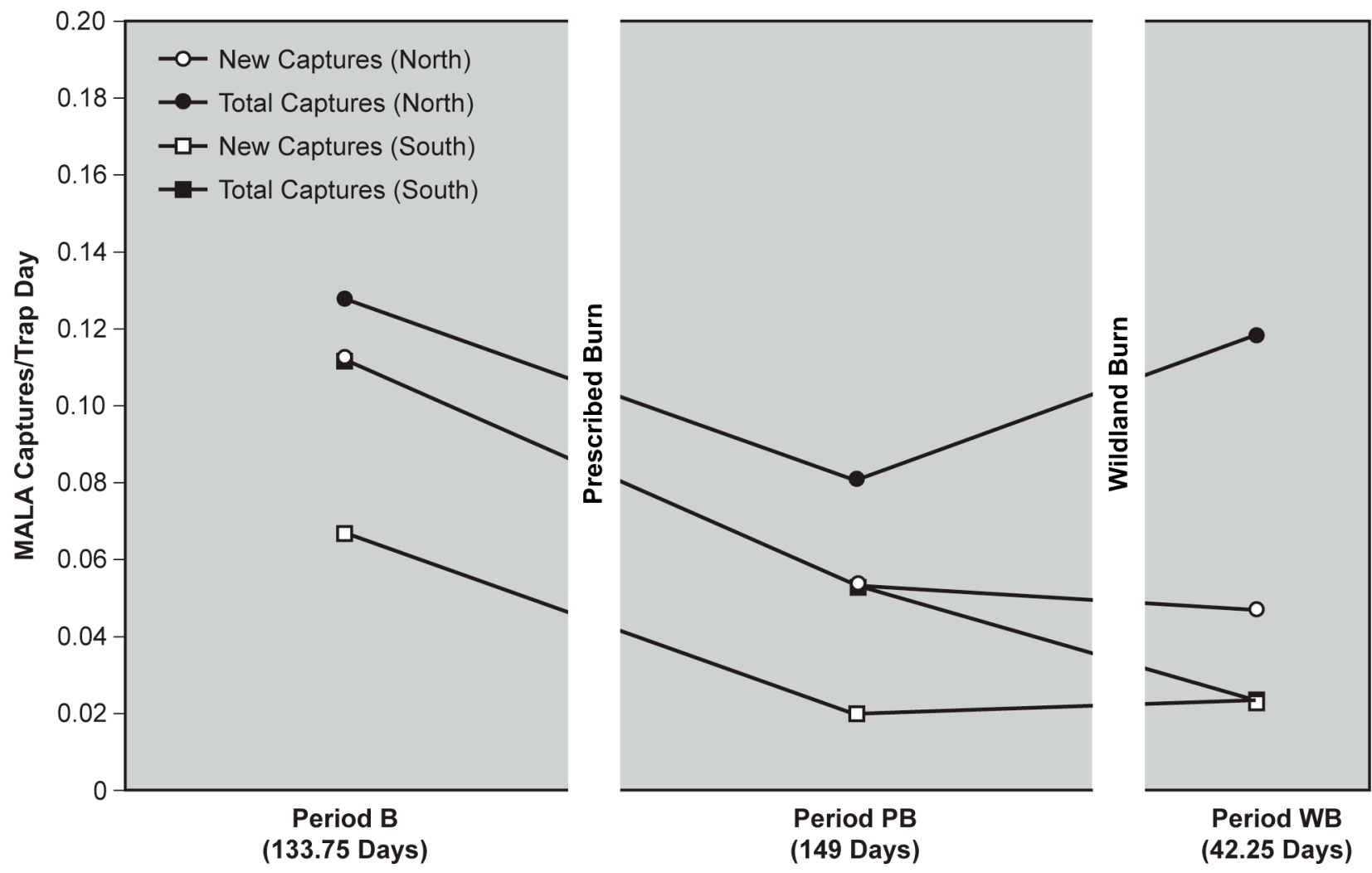

Figure 3. MALA capture rate during Period $B, P B$, and $W B$ showing new snakes and total snakes (includes recaptures) trapped according to North or South scrubland site. 


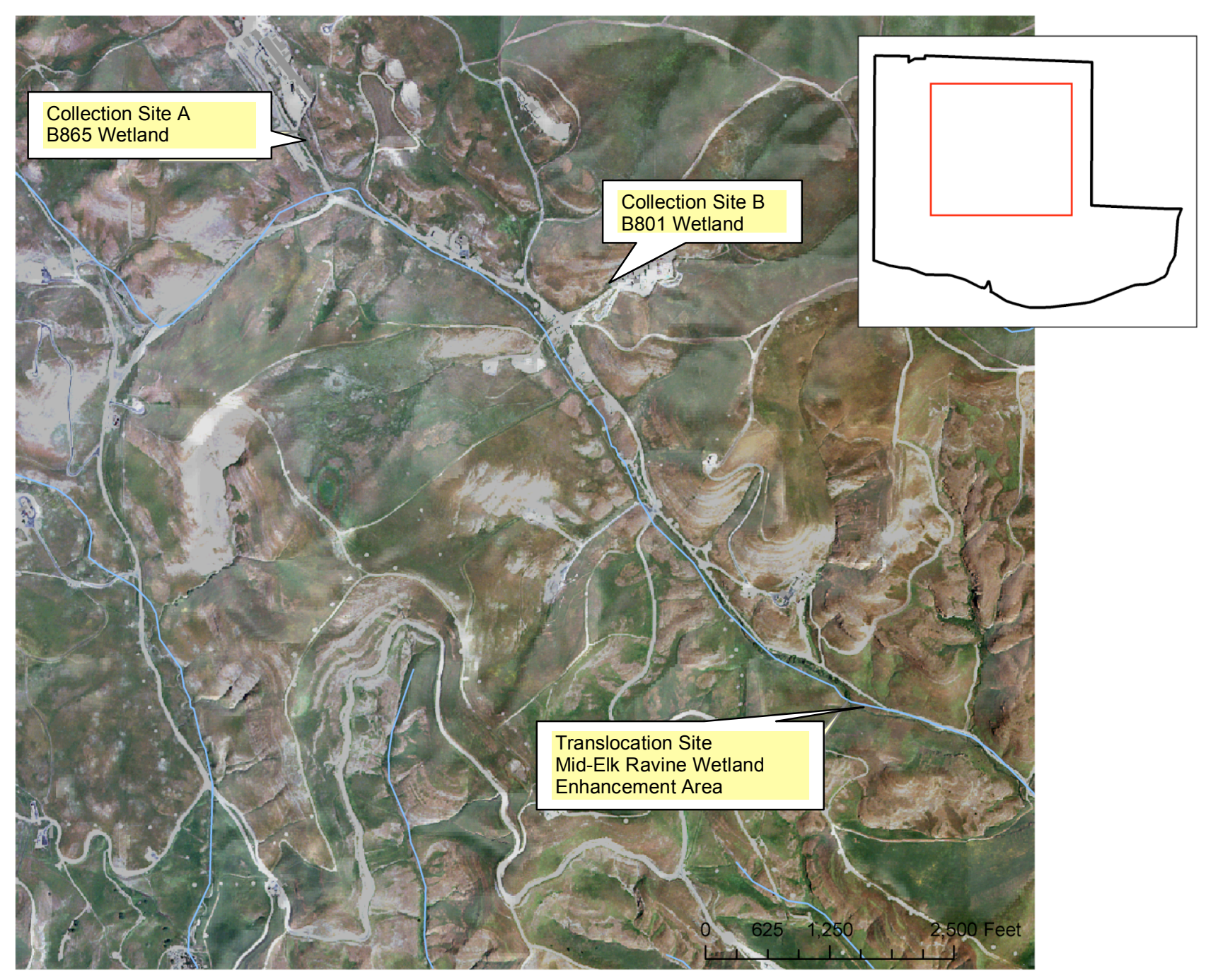

Figure 4. California red-legged frog collection sites and translocation area. 